DOI: https://doi.org/10.32838/2523-4803/70-1-8

удК 336.027

\title{
Гомон М.В.
}

аспірантка кафедри митної справи та оподаткування,

Харківський національний економічний університет імені Семена Кузнеця

\section{Homon Maryna}

Simon Kuznets Kharkiv National University of Economics

\section{ТЕОРЕТИЧНЕ ОБГРУНТУВАННЯ СТРУКТУРНИХ ЕЛЕМЕНТІВ РЕГУЛЯТИВНОГО ПОТЕНЦАЛУ ПІЛЬГОВОГО ОПОДАТКУВАННЯ ІННОВАЦІЙНОЇ ДІЯЛЬНОСТІ}

\begin{abstract}
Статтю присвячено питанню теоретичного обтрунтування регулятивного потенціалу пільгового оподаткування інновачійної діяльності, зокрема його структурним елементам. Обгрунтовано сутність реалізації регулятивного потенџіалу податкових пільг в інноваційній діяльності, виражену в збільшенні інноваційних витрат та обсягу вивільнених коштів підприємства. Проведено аналіз елементного складу регулятивного потенціалу пільгового оподаткування інноваційної діяльності, визначено принщипи, мету та напрями реалізащії регулятивного потенціалу пільгового оподаткування. Виявлено, щчо реалізаџія регулятивного потенціалу за допомогою таких інструментів, як податкові пільги та дотримання основних принципів податкового регулювання, спрямована на стимулювання інноваційної діяльності суб 'єктів господарювання і підтримку державної стратегії інноваційного розвитку.
\end{abstract}

Ключові слова: потенціал, податкове регулювання, податкові пільги, стимулювання, інновачійна діяльність.

Постановка проблеми. Важливість інноваційної сфери в економіці вказує на те, що вона потребує певних регулятивних процесів, які змогли б стимулювати ii розвиток. Серед різних процесів державного регулювання важливе місце посідає податкове регулювання. Серед багатьох країн пільгове оподаткування $є$ одним із методів податкової політики, спрямованої на інноваційний розвиток. Це вказує на те, що податкові пільги мають регулюючий вплив на інноваційну сферу, зокрема на стимулювання інноваційної діяльності. Саме тому питання регулятивного потенціалу пільгового оподаткування інноваційної діяльності та його структури вважається відкритим для досліджень.

Високий рівень та продуктивність технологічних знань в Україні не мають можливості повною мірою реалізувати себе через нестабільність та неефективність влади та недосконалість державного регулювання. Така ситуація ще раз вказує на необхідність розвитку та вдосконалення державного регулювання інноваційної діяльності, у тому числі за допомогою реалізації регулятивного потенціалу пільгового оподаткування, що дасть можливість підвищити рівень інноваційного розвитку, а разом із ним і конкурентоспроможність України серед країн світу.

Аналіз останніх досліджень і публікацій. Дослідженням державного податкового регулювання та податкових пільг як інструмента стимулювання інноваційної діяльності присвячено багато наукових праць таких науковців, як І.В. Алексєєв, Ю.Б. Іванов,
Л.В. Касьянова, М.О. Кизим, Р.Ю. Кризька, А.І. Крисоватий, О.І. Олексюк, Д.М. Серебрянський, А.М. Соколовська, Л.Л. Тарангул.

Незважаючи на всю цінність попередніх наукових здобутків, питання регулятивного потенціалу інструментів державного регулювання інноваційної діяльності та його елементної структури розкрито недостатньо.

Формулювання цілей статті. Метою даної статті $\epsilon$ визначення елементного складу регулятивного потенціалу пільгового оподаткування інноваційної діяльності для подальшої оцінки реалізації такого потенціалу.

Виклад основного матеріалу. Поняття «регулятивний потенціал» пов'язане із системою податкового регулювання, оскільки за своєю сутністю це поняття означає використання наявних можливостей регулюючого впливу для досягнення певних цілей, що відповідає завданням податкового регулювання та виражається у тому, наскільки повно й ефективно податкові пільги можуть виступати у ролі інструменту реалізації регулятивної функції податків.

Сутність регулятивного потенціалу пільгового оподаткування для інноваційної діяльності підприємства зображено на рис. 1 .

Звільнене від сплати податків підприємство отримує вивільнені фінансові ресурси, які можуть бути використані на збільшення обсягу витрат на інновації. Збільшуючи інноваційні витрати, підприємство інтен- 
сифікує виконання та реалізацію досліджень, розробок і проєктів. Також такі вивільнені кошти можуть бути витрачені на утримання та функціонування підприємства, виплати працівникам. Окрім того, вивільнені внаслідок меншої сплати податків кошти можуть бути реінвестовані в подальшу інноваційну діяльність, тим самим відбувається стимулювання інноваційного розвитку за допомогою пільгового оподаткування.

Формування регулятивного потенціалу пільгового оподаткування інноваційної діяльності підприємства має здійснюватися відповідно до принципів (табл. 1).

Ураховуючи принципи та мету реалізації регулятивного потенціалу пільгового оподаткування, можемо систематизувати такий потенціал за складовими елементами (рис. 1).

Виходячи $з$ наведених принципів, можна сформулювати мету реалізації регулятивного потенціалу пільгового оподаткування інноваційної діяльності - поліпшення фінансово-економічних результатів діяльності інноваційних підприємств та підвищення економічної зацікавленості суб'єктів господарювання в інноваційному розвитку.

З огляду на рис. 1, об’єктом регулятивного потенціалу пільгового оподаткування $є$ інноваційний процес, однак для якомога повнішої оцінки результативності пільгового оподаткування варто вибрати за об'єкт стимулювання не інноваційний процес, а інноваційну діяльність підприємства. Результатом діяльності є збільшення прибутку та розвиток підприємства, тому, зважаючи на такі об'єкт та результат, пропонується вибрати ціллю застосування податкових пільг із метою стимулювання збільшення обсягу інноваційних витрат підприємством, мотиваційним складником якої $\epsilon$ зменшення податкового тягаря на суму наданих податкових пільг.
Реалізація регулятивного потенціалу пільгового оподаткування інноваційної діяльності здійснюється на макро- та мікрорівнях. Доцільно розподілити ці рівні реалізації за ознаками суб'єкта регулюючого впливу та цілі регулювання.

Так, суб'єктами регулюючого впливу на макрорівні виступають (але у межах країни) технопарки, технополіси, ТНК, науково-технічні комплекси, інноваційні фонди.

На мікрорівні суб'єктами виступають інноваційні підприємства, підприємства реального сектору, що впроваджують інновації, науково-дослідні організації, венчурні фірми, університети.

Застосування інструментів оподаткування $є$ однією 3 передумов розвитку інноваційної діяльності. За формою впливу на інноваційну діяльність податкове стимулювання належить до непрямих методів державного управління, воно полягає у відмові держави від частини податкових надходжень в обмін на зростання обсягу інноваційної продукції з урахуванням визначених державою пріоритетів. Своєю чергою, зростання обсягів виробництва такої продукції призводить до збільшення суми податкових надходжень. За умови, коли останнє перевищує суму наданих податкових пільг, податкове стимулювання стає економічно вигідним для держави [1].

Поняття податкової пільги найбільш повно розкрито у визначенні Ю.Б. Іванова та І.А. Майбурова: податкова пільга - це передбачене податковим законодавством відхилення від базової (нормативної) структури податку, зумовлене досягненням завдань соціально-економічної політики держави, що дає змогу окремим категоріям платників податків отримувати ті чи інші переваги, які полягають у полегшенні податкового тягаря [2].

Таблиця 1

Принципи реалізації регулятивного потенціалу пільгового оподаткування інноваційної діяльності

\begin{tabular}{|c|c|}
\hline Принцип & Сутність \\
\hline системності & $\begin{array}{l}\text { формування відкритої, динамічної, імовірнісного характеру системи управління інноваційним } \\
\text { розвитком з урахуванням регулятивного потенціалу пільгового оподаткування }\end{array}$ \\
\hline адаптивності & $\begin{array}{l}\text { підтримання балансу зовнішніх, сформованих ринковим середовищем, і внутрішніх можливостей } \\
\text { інноваційного та фінансового розвитку суб'єкта господарювання }\end{array}$ \\
\hline самоорганізації & $\begin{array}{l}\text { самостійне забезпечення підтримки обміну різними видами ресурсів між структурними } \\
\text { складовими підприємства (зокрема, департаментами інноваційного розвитку й фінансовим) та між } \\
\text { підприємством, зовнішнім середовищем і державою }\end{array}$ \\
\hline саморегуляції & $\begin{array}{l}\text { коригування системи управління інноваційним розвитком підприємства відповідно до змін } \\
\text { зовнішнього середовища у сфері пільгового оподаткування (зокрема, законодавства, умов та } \\
\text { можливостей використання пільгового оподаткування) }\end{array}$ \\
\hline ефективності & $\begin{array}{l}\text { зростання прибутку, розширення масштабів виробництва і можливостей нагромадження капіталу, } \\
\text { підвищення конкурентоспроможності підприємства }\end{array}$ \\
\hline керованості & $\begin{array}{l}\text { забезпечення відповідності фактичного стану інноваційного процесу бажаному (запланованому) } \\
\text { стану після реалізації системної трансформації }\end{array}$ \\
\hline збалансованості & $\begin{array}{l}\text { інноваційні процеси і проєкт використання пільгового оподаткування повинні бути узгоджені у часі } \\
\text { та термінах реалізації й являти собою єдиний процес }\end{array}$ \\
\hline саморозвитку & $\begin{array}{l}\text { самостійне забезпечення умов функціонування підприємства відповідно до прийнятої стратегії } \\
\text { розвитку }\end{array}$ \\
\hline невизначеності & $\begin{array}{l}\text { необхідність достовірного прогнозування і планування стратегії інноваційного росту, створення } \\
\text { фінансових резервів для зменшення можливих негативних наслідків від можливих ризиків чи } \\
\text { коректування строків виконання окремих інноваційних робіт (стадій, етапів) під час їх планування }\end{array}$ \\
\hline
\end{tabular}




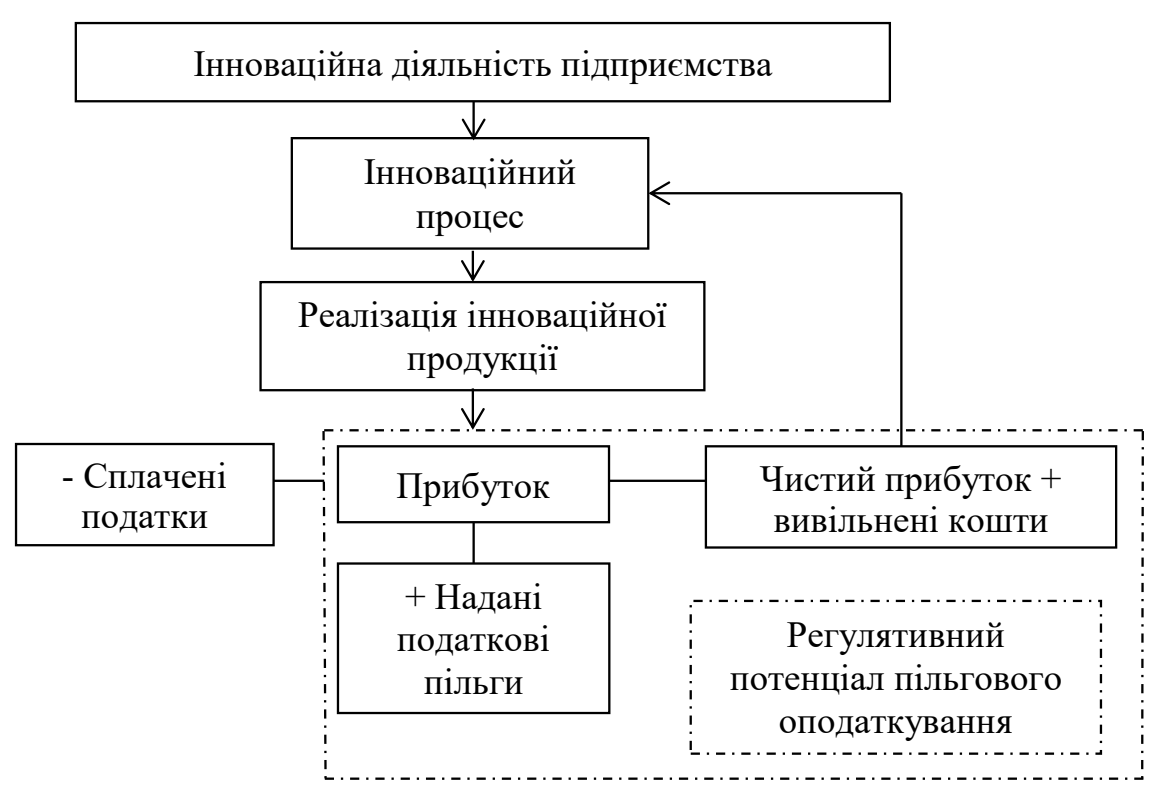

Рис. 1. Сутність регулятивного потенціалу пільгового оподаткування інноваційної діяльності

Як інструменти податкового регулювання податкові пільги можуть надаватися шляхом [3]: податкового вирахування (знижки), що зменшує базу оподаткування до нарахування податку та збору. База зменшується не за рахунок виключення з ії складу певних об'єктів, податкова база зменшується на грошову суму, встановлену законодавством. Вирахування 3 податкової бази певної законодавчо встановленої суми. Можливі шляхи зменшення розміру податкової бази:

- встановлення неоподатковуваного мінімуму податкової бази;

- встановлення неоподатковуваного максимуму податкової бази;

- пряме виключення з податкової бази законодавчо встановлених сум;

- подальше зменшення податкової бази шляхом вирахування суми фактично понесених платником витрат певного типу (податкова знижка).

Податкові пільги, що мають стимулюючий вплив, зазвичай носять інвестиційний чи інноваційний характер та передбачають реальну і відчутні віддачу для держави у вигляді розширення податкової бази, збільшення податкових надходжень до державного бюджету, збільшення кількості робочих місць тощо [4].

Варто зупинитися на стимулюючій спрямованості податкових пільг, оскільки саме ця характерна риса відображає здатність податкових пільг як інструменту податкового регулювання здійснювати стимулюючий вплив на результати інноваційної діяльності підприємства. Також стимулюючий вплив можна віднести до прояву регулятивного потенціалу податкових пільг.

Що стосується напрямів реалізації регулятивного потенціалу пільгового оподаткування інноваційної діяльності, то можна виділити такі:
- підтримка реалізації інноваційних проєктів або діяльності інноваційних організацій; зниження вартості наукового та інноваційного продукту (робіт, послуг) за рахунок зниження податкового складника в їх ціні;

- розширення попиту на інноваційну продукцію;

- стимулювання залучення інвестицій в інноваційну діяльність;

- стимулювання реінвестування прибутку в інноваційний процес;

- створення стимул-реакцій для розширення попиту на наукові дослідження;

- створення стимул-реакцій для інвестування в науку та інноваційну сферу;

- підтримка малих інноваційних підприємств.

Напрями, представлені на рис. 2, завдяки підвищенню рівня попиту дадуть змогу розширити можливості проведення наукових досліджень та створення інноваційної продукції. Зниження ціни товарів (робіт, послуг) за рахунок зменшення в їхній вартості податкового складника у вигляді зменшення податкового тягаря на суму наданих пільг може призвести до привабливості для інвесторів проєктів, які були б невигідними без застосування спеціальних податкових пільг.

Висновки. Дослідження елементів регулюючого потенціалу пільгового оподаткування інноваційної діяльності надає можливість подальшого оцінювання регулятивного потенціалу податкових пільг, зокрема його результативності. Надання податкових пільг може стимулювати інноваційні витрати і тим самим активізувати інноваційну діяльність, впливає на зменшення рівня податкового навантаження підприємства і тим самим збільшує його прибуток, який підприємство може реінвестувати у свій подальший розвиток. 


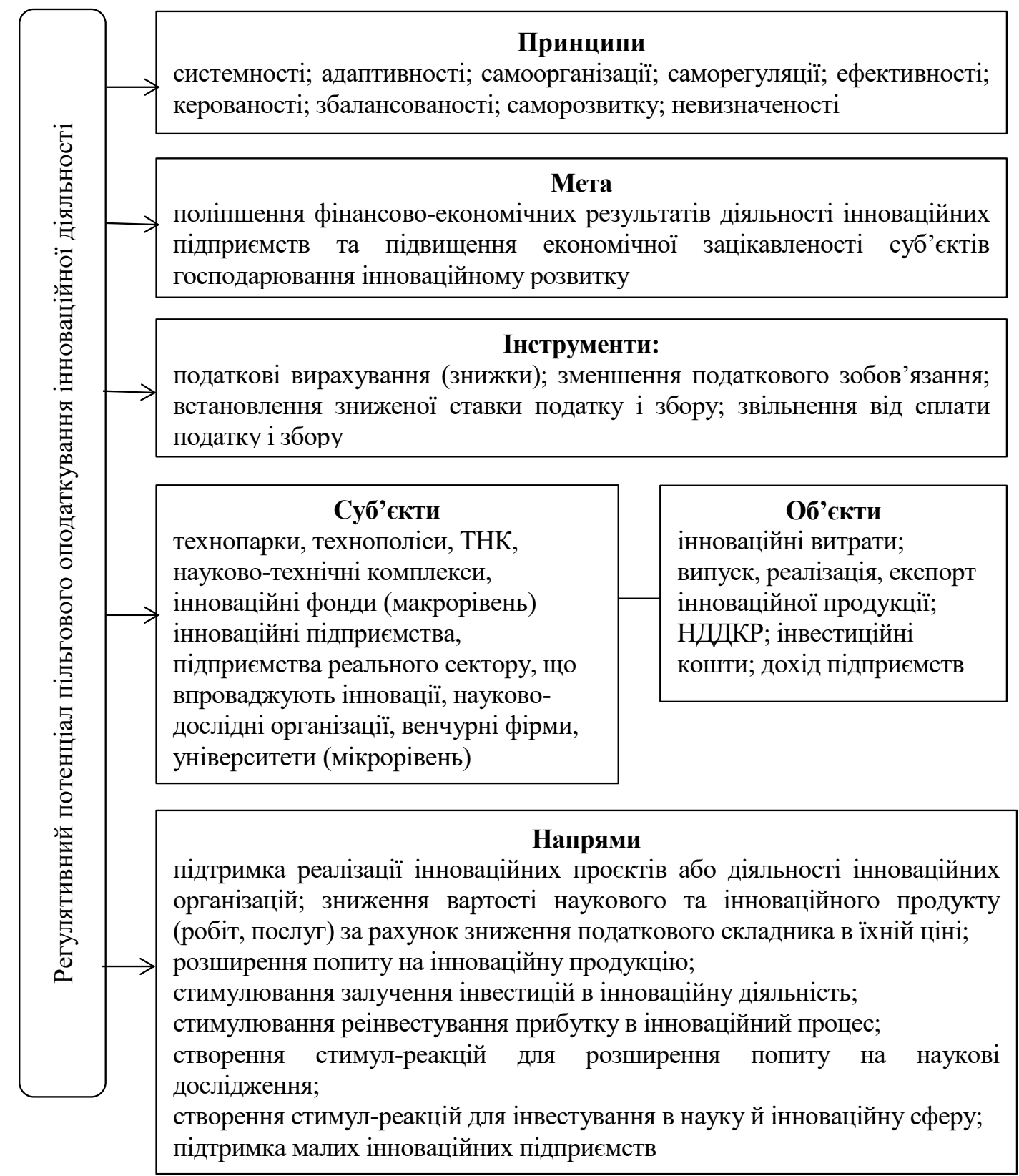

Рис. 2. Елементи регулятивного потенціалу пільгового оподаткування інноваційної діяльності

\section{Список літератури:}

1. Олексюк О.І. Нові методологічні аспекти вивчення потенціалу акціонерних товариств. Стратегія економічного розвитку Украӥни. 2000. Вип. 4. С. 74-95.

2. Майбуров И.А., Иванов Ю.Б. Налоговые льготы. Теория и практика применения : монография / под ред. И.А. Майбурова, Ю.Б. Иванова. Москва : ЮНИТИ-ДАНА, 2014. 487 с.

3. Податковий кодекс України від 2 грудня 2010 р. № 275 - VI / Верховна Рада України. URL : http://zakon2.rada.gov.ua (дата звернення: 18.01.2020).

4. Коротун В.І. Практика використання податкових пільг в Україні. Вісник ЖДТУ. 2012. № 1(59). С. $267-270$.

\section{References:}

1. Oleksyuk O. I. (2000) Novi metodolohichni aspekty vyvchennya potentsialu aktsionernykh tovarystv [New Methodological Aspects of Studying the Potential of Joint Stock Companies]. Economic Development Strategy of Ukraine, vol. 4 , pp. $74-95$. 
2. Mayburov I. A, Ivanov Yu. B. (2014) Nalogovyye l'goty. Teoriya i praktika primeneniya [Tax exemptions. Theory and practice of application]. Moscow: UNITY-DANA. (in Russian)

3. Podatkovyi kodeks Ukrainy vid 2 hrudnia 2010 r. № 275 - VI [Tax Code of Ukraine of December 2, 2010 № 275 - VI]. Verkhovna Rada of Ukraine. Available at: http://zakon2.rada.gov.ua (accessed 18.01.2020).

4. Korotun V. I. (2012) Praktyka vykorystannya podatkovykh pil'h v Ukrayini [The practice of using tax benefits in Ukraine]. ZhSTU Bulletin, no. 1, pp. $267-270$.

\section{ТЕОРЕТИЧЕСКОЕ ОБОСНОВАНИЕ СТРУКТУРНЫХ ЭЛЕМЕНТОВ РЕГУЛЯТИВНОГО ПОТЕНЦИАЛА ЛЬГОТНОГО НАЛОГООБЛОЖЕНИЯ ИННОВАЦИОННОЙ ДЕЯТЕЛЬНОСТИ}

Статья посвящена вопросу теоретического обоснования регулятивного потенциала льготного налогообложения инновационной деятельности, в частности его структурным элементам. Обоснована сущиость реализации регулятивного потенцииала налоговых льгот в инновационной деятельности, выраженной в увеличении инновационных затрат и объема высвобожденных средств предприятия. Проведен анализ элементного состава регулятивного потенциала льготного налогообложения инновационной деятельности, определены принципь, иели и направления реализации регулятивного потенцииала льготного налогообложения. Выявлено, что реализация регулятивного потенциала с помощью таких инструментов, как налоговые льготы и соблюдение основныхх принщипов налогового регулирования, направлена на стимулирование инновационной деятельности субъектов хозяйствования и поддержку государственной стратегии инновационного развития.

Ключевые слова: потенциал, налоговое регулирование, налоговые льготы, стимулирование, инновационная деятельность.

\section{THEORETICAL JUSTIFICATION STRUCTURAL ELEMENTS OF THE REGULATORY POTENTIAL OF PREFERENTIAL TAXATION IN INNOVATIVE ACTIVITIES}

The article is devoted to the theoretical substantiation of the regulatory potential of preferential taxation of innovative activity, in particular - to its structural elements. In many countries, preferential taxation is one of the methods of tax policy aimed at innovative development. This indicates that tax benefits have a regulatory impact on the innovation sphere, in particular on stimulating innovation. That is why the question of the regulatory potential of preferential taxation of innovation activity and its structure is considered relevant. It is determined that the concept of "regulatory potential" is linked to the system of tax regulation, because in its essence this concept means the use of available regulatory influence to achieve certain goals, which meets the objectives of tax regulation and is expressed in how fully and effectively tax benefits may act as a tool for implementing the regulatory tax function. Taking into account the principles and purpose of realization of the regulatory potential of preferential taxation, we can systematize the regulatory potential of preferential taxation of innovative activity by its constituent elements. The essence of realization of regulatory potential of tax privileges in innovative activity, expressed in increase of innovative expenses and volume of released funds of the enterprise is substantiated. The elemental composition of the regulatory potential of preferential taxation of innovative activity is analyzed, the principles, purpose and directions of realization of the regulatory potential of preferential taxation are determined. It is revealed that the realization of regulatory potential with the help of tools such as tax breaks and in compliance with the basic principles of tax regulation is aimed at stimulating the innovation activity of economic entities and supporting the state strategy of innovation development. The study of the elements of the regulatory potential of preferential taxation of innovative activity provides an opportunity for further evaluation of the regulatory potential of tax benefits, in particular - its effectiveness.

Key words: potential, tax regulation, tax benefits, stimulation, innovation. 